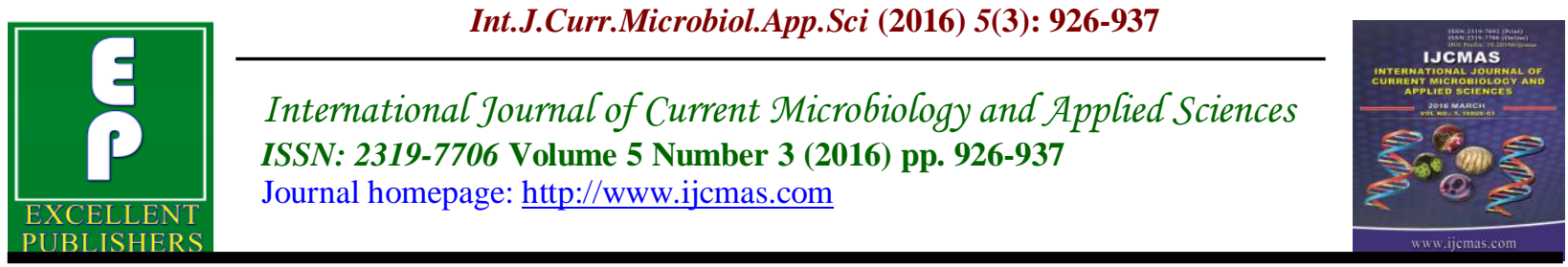

Original Research Article

http://dx.doi.org/10.20546/ijcmas.2016.503.107

\title{
Biological synthesis of Silver nanoparticles (Ag-NPS) by Lawsonia inermis (Henna) plant aqueous extract and its antimicrobial activity against human pathogens
}

\author{
K. Satheesh Kumar and P. Kathireswari* \\ PG and Research Department of Zoology, Kongunadu Arts and Science College, \\ Coimbatore-641 029, Tamil Nadu, India \\ *Corresponding author
}

\begin{abstract}
A B S T R A C T
Keywords

Medicinal plants,

Biological

Synthesis,

Eco-friendly,

Lawsonia inermis,

Silver ions,

Ag-NPs,

Characterization,

Anti microbial

activity

Article Info

Accepted:

20 February 2016

Available Online:

10 March 2016

Medicinal plants have a higher safety margins in curing the diverse range of diseases caused by micro-organisms, due to their rich source in bioactive molecules. The biological route for synthesizing $\mathrm{Ag}-\mathrm{Np}_{\mathrm{s}}$ by using those plants serves as a straight forward approach, to explore an alternative approach which has greater effect on killing drug resistant pathogenic microbes. In the present study an attempt has been made to determine the efficiency of antibacterial activity of Lawsonia inermis (Henna plant) aqueous extract has been encountered, due to their wide array of phyto-chemicals present in them, the effect of $L$. inermis aqueous extract by challenging with $1 \mathrm{mM} \mathrm{AgNo}_{3}$ and formation of Ag-NPs were subjected for characterization process viz., UV-Vis, SEM with EDAX, XRD, ZETA Potential analysis and Particle size distribution. The results revealed that the presence of grain sized $\mathrm{Ag}-\mathrm{NP}_{\mathrm{s}}$ was confirmed. Finally anti-bacterial activity was done by disc diffusion method against Gram- Positive \& Gram - Negative bacterial strains which causes infectious diseases in humans. Their positive results showed that, they have great potential as anti-microbial compounds against pathogenic microbes studied and it can be used in the treatment of infectious diseases caused by bacteria.
\end{abstract}

\section{Introduction}

Nanotechnology discoveries in the past decade have clearly demonstrated in solving many problems faced by humanity. One of the most important area is medicinal field, in which the nano engineered particles are used which are harmless, non-toxic to the human body and which cures lot of problems in quick succession. There is a tremendous production \& excitement in the study of nanoscale matters having nanometer dimensions $\left(10^{-9} \mathrm{~nm}\right)$. One of the key aspects of nanotechnology field concerns is the development of reliable, confinement in the knowledge of materials \& experimental protocols used for synthesis of nanomaterials. Over a range of chemical 
compositions, their physical properties, toxicity in various applications \& high mono-dispersity assumes considerable importance and it's termed as quantum confinement ${ }^{(1-8)}$.

An important area of research in nanotechnology deals with the biomimetic synthesis of nanoparticles by using biological sources like plant leaf, bacteria, fungi, etc., which offers numerous benefits of eco-friendliness \& effective in various medicinal applications as they do not use any toxic chemicals in the synthesis protocol. In early days nanoparticles aroused primarily by either physical or chemical methods by using non-deleterious solvents or substances like hydrazine, sodium borohydride, hydrogen, heavy metals, etc and radiation chemicals which causes great damage in the environment as well as side effects in the health ${ }^{(9-12)}$. To overcome this problem, bio-inspired synthesis of nanoparticles as a choice by targeting in wide range has been carried out ${ }^{(13)}$.

In this present study Lawsonia inermis (Henna) plant has been used as a biological source for synthesizing silver nanoparticles. L.inermis is a small shrub which has its unique bio-active principles like Sugars, Fraxetin, Tannin, Gallic acid, Lawsone, Resins, Coumarins, etc in their leaves. Among those Lawsone is the major ingredient which gives its characteristic colour(lavhate,2007). This plant has been used in medicinal field since ancient times. This is the only plant known which possess healing attributes and now it is used in intense scientific study ${ }^{(4-9)}$. The leaves of this plant are used in the treatments of wounds, ulcers, cough, bronchitis, lumbago, rheumatagia, inflammations, diarrhoea, dysentery, leucoderma, scabies, boils, anaemia, haemorrhages, fever, falling of hair and greyness hair (14-17). The medicinal properties exhibited by this plant mainly due to its wide range of phyto-chemical compounds present in them. These includes 1,4-Naphoquinone, 2-Hydroxy-1,4Naphthoquinone, Aesculelin, $\beta$-Sitosterol, Esculetin, Cosmosiin, Laloiside, Quinone, Scopoletin, Tiliani, etc ${ }^{(18-19)}$.

Therefore, this study aims to explore the biomimetic synthesis and its efficacy as a source of nano-medicine against various bacterial strains and to establish their therapeutic values in anti-bacterial potential of plant with nanotechnology has been highlighted. In future, these alternatives may be very useful in treating the infections caused by the microbes.

\section{Materials and Methods}

\section{Materials}

The chemical Silver Nitrate $\left(\mathrm{AgNO}_{3}\right)$ was purchased from the precision chemicals Pvt.,Ltd., Coimbatore.

\section{Plant Sample Collection}

The leaves of Lawsonia inermis (Henna) plant was collected freshly from the local nursery garden from near to the college. The plant was identified Lawsonia inermis (Henna) at the Department of Botany, Kongunadu Arts \& Science College, Coimbatore, Tamil Nadu, India.

\section{Extract Preparation of L. inermis (Henna)}

Fresh and healthy leaves of $L$. inermis (Henna) was collected and rinsed them with tap water followed by de-ionised water and allowed to air dry few minutes. After that they were cut into small pieces and about 10 grams was taken in $250 \mathrm{ml}$ conical flask containing $100 \mathrm{ml}$ distilled water and boiled them for 10 minutes. After cooling they are 
filtered thrice by using Whatmann No.1 filter paper and the extracts are collected and stored them at $4^{0} \mathrm{c}$ which was used for further work.

\section{Biogenic Synthesis of Ag-NPs}

Aqueous extract $(10 \mathrm{ml})$ of plant which was prepared is taken in a $150 \mathrm{ml}$ conical flask and $90 \mathrm{ml}$ of $1 \mathrm{mM}$ of $\mathrm{AgNo}_{3}$ was added \& kept at room temperature for reduction process and change of colour was monitored. Entire process was carried out in darkness to avoid photoactivation of $\mathrm{AgNo}_{3}$ at room temperature.

Detection and Characterization of AgNPs

The bioreduction of silver ions in L.inermis (Henna) plant aqueous extract was monitored $b$ various characterization process.

\section{UV-Vis Spectroscopy}

The pre-liminary bio-reduction of $\mathrm{Ag}^{+}$in aqueous solution was detected by UV-Vis spectrophotometer (Perkin-Elmer lamda-25) at room temperature with the wavelengths of $200 \mathrm{~nm}-800 \mathrm{~nm}$ at a resolution of $1 \mathrm{~nm}$ to analyse the Surface Plasmon Resonance band.

\section{Scanning Electron Microscopy}

The morphology of synthesized nanoparticles was examined by using Scanning Electron Microscopcic analysis. The reaction solution containing silver nanoparticles synthesized from L.inermis leaf extract was made into powder by using Lyophilizer equipment. Thin flims of sample were prepared on carbon coated grids and SEM analysis were done. The images of biomimetic silver nanoparticles were obtained in SEM (Fb- Quanta 200 SEM machine) operated at $30 \mathrm{kV}$ at different magnification level.

\section{Energy-Dispersive X-ray (EDX) Analysis}

The synthesized silver nanoparticles using L.inermis aqueous extract subject to the Energy Dispersive Spectrum using SEM attached Fb-Quanta- 200 resolution to confirm the presence of silver in the particles as well as to detect other elementary compositions of the particle.

\section{XRD Analysis}

The bio-reduced silver nanoparticles are dried in powder form by using lyophilizer equipment and they are coated on XRD grid and analysed for the formation of nanoparticles by using Philips PW-1830 XRay Diffractometer. X-Ray generator operated at a voltage of $40 \mathrm{kV}$ and tube current of $30 \mathrm{~mA}$ with $\mathrm{Cu} \mathrm{K} \alpha 1$ radiation with $\lambda$ of 1.5406 . The scanning was done in the region of 2 from $30^{\circ}$ to $80^{\circ}$ at $0.02 \mathrm{~min}$ and the time constant was $2 \mathrm{sec}$. The average particle size was determined by using Scherr's formula

$\mathrm{D}=\left(0.9 \lambda \times 180^{\circ}\right) \div \beta \cos \theta$

\section{Particle Size Distribution Analysis}

The synthesized silver nanoparticles using L.inermis aqueous extract was subject to particle size distribution analysis by using ZETA sizer version 6.32 (MAL 1037088) Malvern instruments.

\section{ZETA Potential Analysis}

ZETA Potential of synthesized Ag-NPs was analysed to determine the ionic charges present in the particles and its stability at $\mathrm{p}^{\mathrm{H}}$ 7. This analysis also provided an idea about 
the size of nanoparticles provided.This analysis was done in ZETA sizer version 6.32 (MAL 1037088) Malvern instruments.

\section{Antimicrobial Assay}

\section{Collection of Microbial Strains}

The selected microbial strains for my present work were collected from the Bioline Laboratory in Coimbatore, Tamil Nadu, India. The collected strains are Five Gram-Positive Bacterial Strains namely (Stapylococcus sps.,Streptococcus aureus, Alpha- haemolytic streptococcus sps.,Betahaemolytic streptococcus sps., Bacillus sps., Streptococcus haemolyticus) and Five Gram Negative Bacterial Strains (Enterococcus faecalis, Escherichia coli, Proteus mirablis, Pseudomonas aruginosa, Klebsiella pneumonia).

\section{Preparation of Inoculums}

A loopful of inoculums of each strains were suspended in $5 \mathrm{ml}$ nutrient broth \& incubated overnight at $37^{\circ} \mathrm{C} \&$ those cultures were used for experiment.

\section{Preparation of Media}

The standard nutrient agar medium at standard concentration was prepared and its $\mathrm{p}^{\mathrm{H}}$ was adjusted to $7 \&$ sterilized by autoclaving at $15 \mathrm{lbs}$ pressure at $121^{\circ} \mathrm{C}$ for 15 minutes.

\section{Sub - Culturing of Microbial Strains}

Pure cultures of micro-organisms were maintained \& stored at $4^{0} \mathrm{C} \&$ used for further experiments.

\section{Anti - bacterial Assay}

Anti - bacterial activity was done by Disc Diffusion Method described by Langfield $e t$ al., (8). Then $0.1 \mathrm{ml}$ of diluted microbial cultures spread on nutrient agar plate. The soaked and dried discs of $6 \mathrm{~mm}$ diameter were placed on seeded plates \& gently pressed down to ensure contact (19-23). Replicates were placed for anti - bacterial activity are Plant Extract (Control), Antibiotic discs (Standard), Pure Silver solution (1mM ), Synthesized $\mathrm{Ag}-\mathrm{NP}_{\mathrm{s}}$ of L.inermis (Henna) (Experimental disc) and Synthesized Ag-NPs of L.inermis (Henna) combined with Standard antibiotic disc to confirm the inhibition zone and plates were incubated at $37^{0} \mathrm{C}$ for 24 hours. After incubation period, Zone of inhibition around the disc were measured \& recorded.

\section{Results and Discussion}

A wide range of secondary metabolites are presented in the plant extracts, nanoparticles produced by plants are more stable and the rate of synthesis is much faster in comparison to other biological sources. In the present study the aqueous silver nitrate solution was reduced during exposure to the Lawsonia inermis (Henna) plant leaf extract at 24- $48 \mathrm{hrs}$ incubation at normal temperature.

\section{Visual observation}

The primary detection was done by visual observation. The formation of silver nanoparticles in the solution of $1 \mathrm{mM}$ $\mathrm{AgNO}_{3}$ \& aqueous extract of Lawsonia inermis (Henna) plant sample was confirmed by change in colour of the mixture from dark brown to colloidal grey which indicates the formation of Ag-NPs compared to the control (without treatment with $\left.1 \mathrm{mM} \quad \mathrm{AgNo}_{3}\right)$ remained dark brown.(Fig 3).

The colour of the reaction mixture changed from dark reddish brown to colloidal brown after $24 \mathrm{hrs}$ incubation. It is well known that 
silver nanoparticles exhibit dark brown colour in water due to extinction of Surface Plasmon Vibration in metal nanoparticles ${ }^{(20)}$. Control (without silver nitrate) shows no colour change, the colour change in the aqueous extract with silver nitrate solution which may be due the presence of bioactive compounds in aqueous extract like Lawsone $\&$ Gallic acid responsible for the reduction of silver nitrate to silver nanoparticles. The different type of antioxidants \& various phyto-chemicals are responsible for the reduction of silver ions, similar type observations were reported by several authors $^{(21-22)}$.

\section{UV-Visible Spectral Analysis}

Formation of silver nanoparticles $\left(\mathrm{AgNP}_{\mathrm{s}}\right)$ by reduction with silver nitrate $\left(\mathrm{AgNO}_{3}\right)$ by aqueous extract of Lawsonia inermis leaf after $24 \mathrm{hrs}$ incubation samples were characterized by UV-Visible Spectroscopy and the results obtained from them confirmed, the biological $\mathrm{AgNP}_{\mathrm{s}}$ formation in reaction mixture. In UV Visible spectrum, a strong, broad peak located between 420nm - 471nm was obsereved (Fig 4). This reveals that the formation of $\mathrm{AgNP}_{\mathrm{s}}$ occurs rapidly within $24 \mathrm{hrs}$ and it is stable even after $24 \mathrm{hrs}$ of completion of the reaction. Similar observations were reported in Geranium leaf extract ${ }^{(18)}$, aqueous extract of Areca nut, pomegranate peel extract ${ }^{(20)}$. In this present study, the synthesized AgNP's were shown characteristic peak at $461 \mathrm{~nm}$ in visible light regions.

\section{SEM Analysis}

SEM analysis shows high-density AgNPs synthesized by L.inermis (Henna) leaf extract. It was shown that relatively spherical and uniform AgNPs were formed with diameter of 13 to $61 \mathrm{~nm}$. The SEM image of silver nanoparticles was due to interactions of hydrogen bond and electrostatic interactions between the bioorganic capping molecules bound to the AgNPs. The nanoparticles were not in direct contact even within the aggregates, indicating stabilization of the nanoparticles by a capping agent. The larger silver particles may be due to the aggregation of the smaller ones, due to the SEM measurements.

\section{EDX Ananlysis}

EDX spectra recorded from the silver nanoparticles were shown in Figure 6. From EDX spectra, it is clear that silver nanoparticles reduced by L.inermis have the weight percentage of silver as $65.91 \%$ and $28.27 \%$. The EDX spectrum of spherical in shape with high aggregation of silver nanoparticles on the surface of the cell prepared with this bioreduction method using L. Inermis (Henna) shown maximum peaks around $3.68 \mathrm{keV}$ correspond to binding energies of silver ions. Throughout the scanning range of binding energies, some additional peaks belonging to bioorganic compound present in the reaction mixture. The EDX analysis revealed strong signals in the silver region and confirms the formation of silver nanoparticles by using biological source. There were other EDX spectrum peaks for $\mathrm{Cl}, \mathrm{Si}, \mathrm{O}$ and $\mathrm{Ca}$ suggesting that they are mixed precipitates present in the plant extract (Usha and Gladys, 2014).

\section{XRD Analysis}

The XRD patterns obtained for the Ag-NPs synthesised using Henna bark extract is shown in Fig.8. The Braggs reflections were observed in the XRD pattern at $2 \theta=32.39$, 27.97, 46.41 and 38.26 These Braggs reflections clearly indicated the presence of (100), (52), (43) and (42) sets of lattice 
planes and further on the basis that they can be indexed as Face- Centred-Cubic (FCC) structure of silver. (Debabrat et al., 2012) reported that the XRD pattern green synthesized silver nanoparticles showed number of Bragg's reflections that may be indexed on the basis of the face centred cubic structure of silver. Since, the present study clearly indicated the X-ray diffraction pattern of biological synthesized silver nanoparticles formed crystalline in nature.

\section{Particle Size Distribution Analysis by Intensity}

Total concentration of $\mathrm{AgNP}_{\mathrm{s}}$ synthesized by Lawsonia inermis was found to be $4.65 \times 10^{9}$ particles $/ \mathrm{ml}$. The size of $\mathrm{AgNP}_{\mathrm{s}}$ analysed shows the ' $Z$ ' range average values of about 154.1 d.nm., with particle distribution rate of about $0.280 / \mathrm{ml}$. The size of the synthesized $\mathrm{AgNP}_{\mathrm{s}}$ is about 20.70 d.nm and its width is about 5.082 d.nm. Distributions of particle size/concentration of AgNPs were shown in Fig.9.

\section{ZETA Potential Analysis}

The synthesized $\mathrm{AgNP}_{\mathrm{s}}$ was found to be stable and the ZETA Potential of these $\mathrm{AgNP}_{\mathrm{s}}$ was measured. The results revealed (Fig. 10) that the ZETA Potential $(\mathrm{mV})$ of synthesized $\mathrm{AgNP}_{\mathrm{s}}$ was -23.5 at $\mathrm{p}^{\mathrm{H}} 7$, which indicates that the nanoparticles are stable ane their conductivity value is about 0.439 $\mathrm{mS} / \mathrm{cm}$.

Table.1 Measurement of Zone of Inhibition (Mm) of Synthesized AgNPs of L.inermis (Henna) Plant against Gram- Positive Bacterial Strains

\begin{tabular}{|c|c|c|c|c|c|}
\hline \multirow{2}{*}{$\begin{array}{c}\text { Test Organisms } \\
\text { (Gram Positive Strains) }\end{array}$} & \multicolumn{5}{|c|}{ ZONE OF INHIBITION (MM) } \\
\hline & $\begin{array}{l}\text { Ampicillin } \\
\text { (Std.) }\end{array}$ & $\begin{array}{c}\text { Pure } \\
\text { Silver } \\
\text { Solution }\end{array}$ & $\begin{array}{c}\text { Pure Plant } \\
\text { Extract } \\
\text { (Con.) }\end{array}$ & $\begin{array}{c}\text { Synthesized } \\
\text { AgNps } \\
\text { (Exp.) }\end{array}$ & $\begin{array}{c}\text { Synthesized } \\
\text { AgNps + } \\
\text { Std. }\end{array}$ \\
\hline Staphylococcus sp. & 7.5 & 7 & 8 & 10 & 15 \\
\hline Streptococcus aureus & 6 & 7 & 10 & 12 & 18 \\
\hline Baillus sp. & 8 & 6 & 12 & 15 & 16.5 \\
\hline$\alpha-$ Haemolytic Streptococcus sp. & 8.5 & 7 & 10 & 14 & 19 \\
\hline$\beta$ - Haemolytic Streptococcus sp. & 6 & 10 & 12 & 15 & 16 \\
\hline Streptococcus haemolyticus & 9 & 9 & 13 & 14 & 18 \\
\hline
\end{tabular}

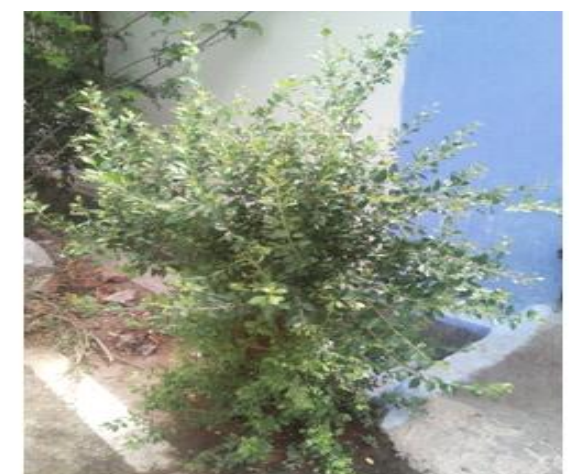

Fig 1 Lawsonia inermis (Henna) plant 
Table.2 Measurement of Zone of Inhibition (Mm) of Synthesized AgNPs of L.inermis (Henna) Plant Against Gram- Negative Bacterial Strains

\begin{tabular}{|c|c|c|c|c|c|}
\hline \multirow{2}{*}{$\begin{array}{c}\text { Test Organisms } \\
\text { (Gram negative } \\
\text { strains) }\end{array}$} & \multicolumn{5}{|c|}{ Zone of Inhibition (mm) } \\
\hline & $\begin{array}{l}\text { Ampicellin } \\
\text { (Std.) }\end{array}$ & $\begin{array}{c}\text { Pure } \\
\text { Silver } \\
\text { Solution }\end{array}$ & $\begin{array}{c}\text { Pure } \\
\text { Plant } \\
\text { Extract } \\
\text { (Con.) }\end{array}$ & $\begin{array}{c}\text { Synthesized } \\
\text { AgNps } \\
\text { (Exp.) }\end{array}$ & $\begin{array}{c}\text { Synthesized } \\
\text { AgNps + } \\
\text { Std. }\end{array}$ \\
\hline $\begin{array}{l}\text { Enterococcus } \\
\text { faecalis }\end{array}$ & 7 & 6 & 9 & 11 & 14.5 \\
\hline $\begin{array}{l}\text { Klebsiella } \\
\text { pneumonia }\end{array}$ & 9 & 7 & 10 & 15 & 17 \\
\hline $\begin{array}{l}\text { Pseudomonas } \\
\text { aruginosa }\end{array}$ & 9 & 7 & 10 & 15 & 16.6 \\
\hline Proteus mirabilis & 9 & 8 & 15 & 12 & 15 \\
\hline Escerichia coli & 8 & 6 & 9 & 12 & 18 \\
\hline
\end{tabular}

Fig.2 Mechanism for Formation of Ag NPs

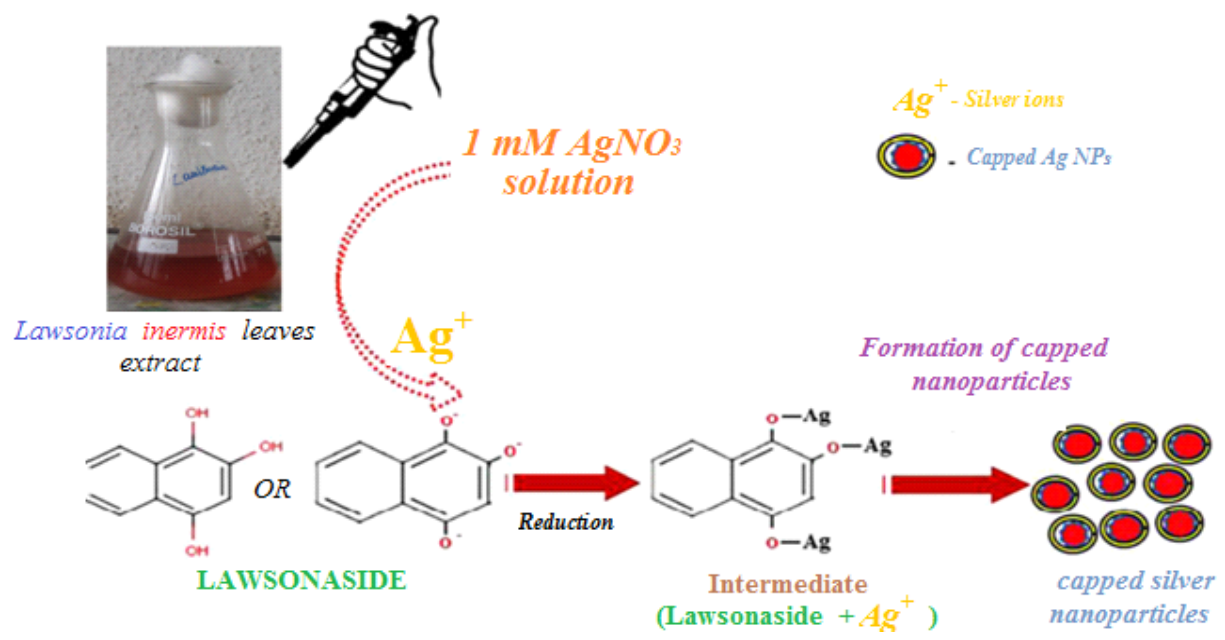

Fig 3 Synthesis of $A g N P_{s}$

(a.) Lawsonia inermis leaves extract (control)

(b.) Extract after treatment with $\mathrm{AgNO}_{3}$

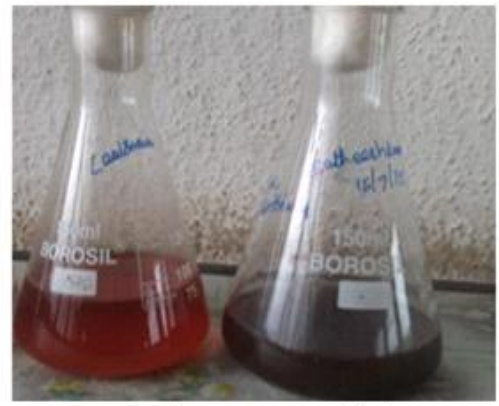

(a.)

(b.) 
Fig.4 : Results of UV - Vis Spectrophotometer Analysis of Lawsonia inermis (Henna)

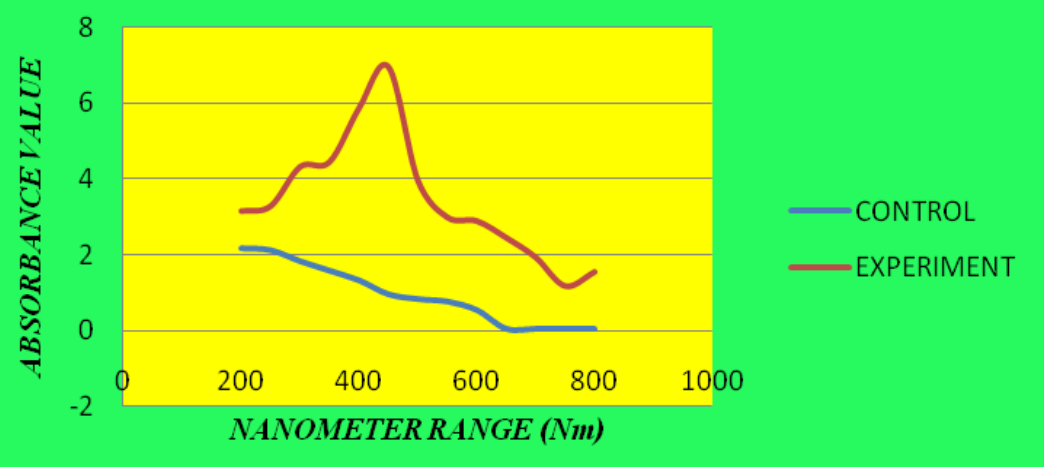

Fig.5 SEM Results of Synthesized AgNPs of L.inermis (Henna)
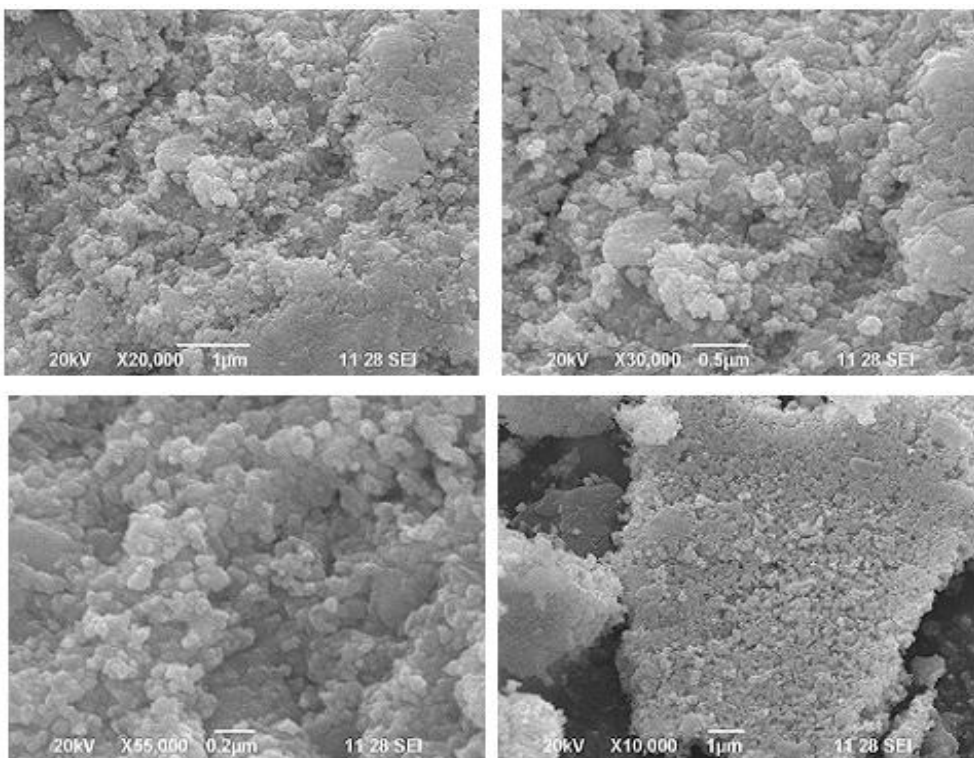

Fig.6 EDX Results of Synthesized AgNPs of L.inermis Henna

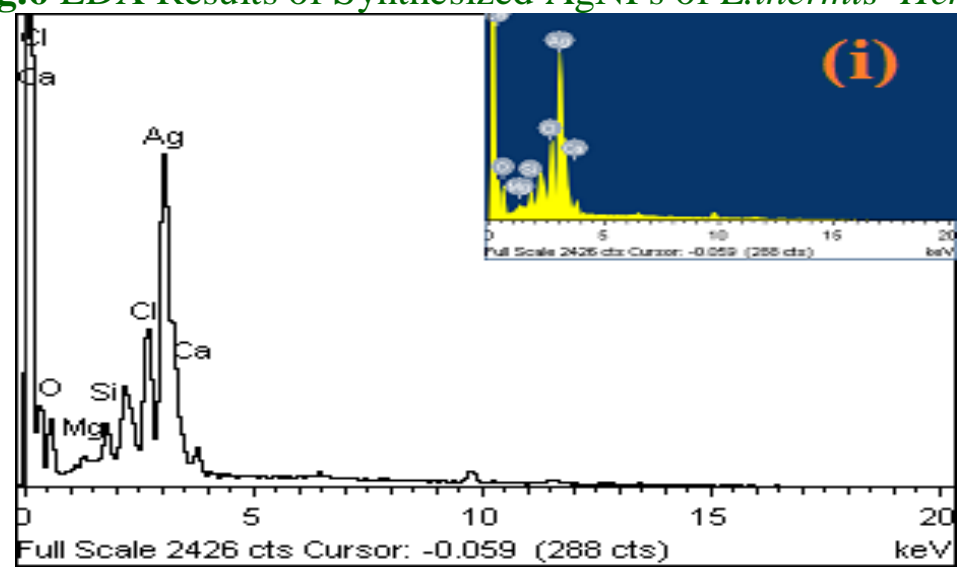


Fig.7 XRD Results of Synthesized AgNPs of L.inermis (Henna)

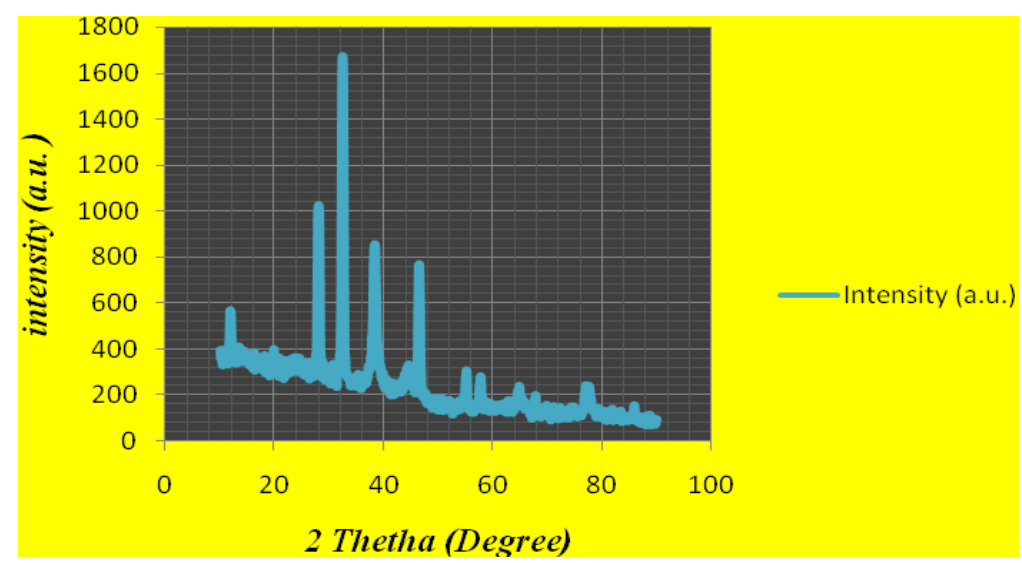

Fig.8 Showing the Results of Particle Size Distribution by Intensity

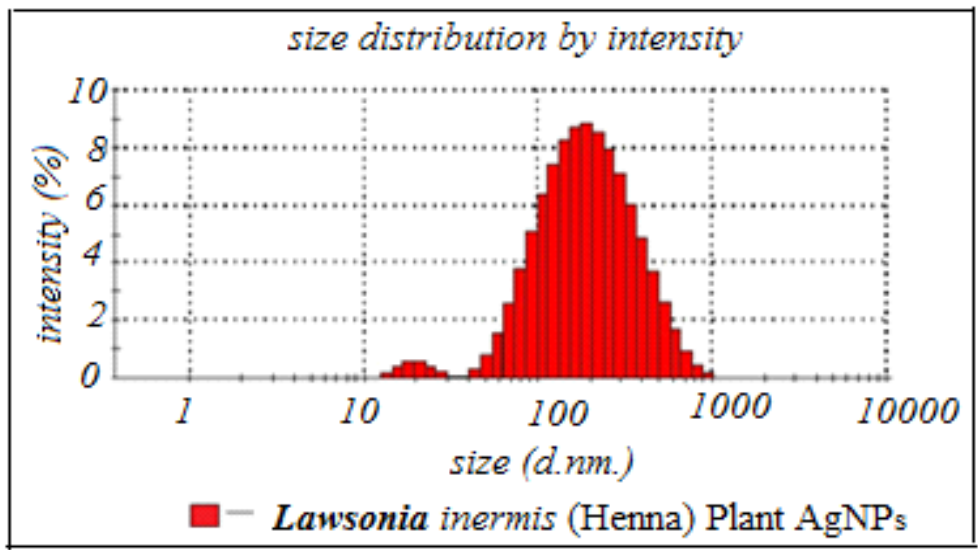

Fig.9 Showing the Results of ZETA Potential

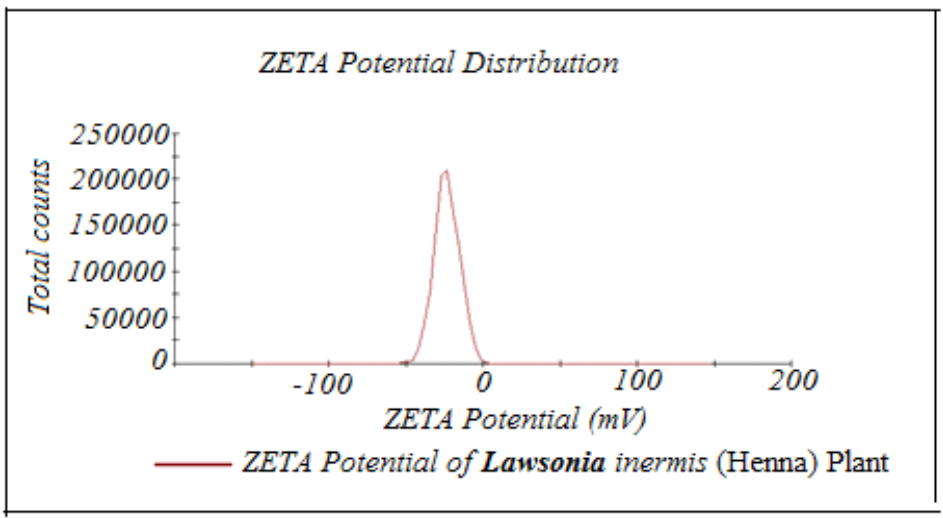


Fig.10 (i) Anti Bacterial Activity of Lawsonia inermis (Henna) against Gram Positive (A) \& Gram Negative (B) Strains

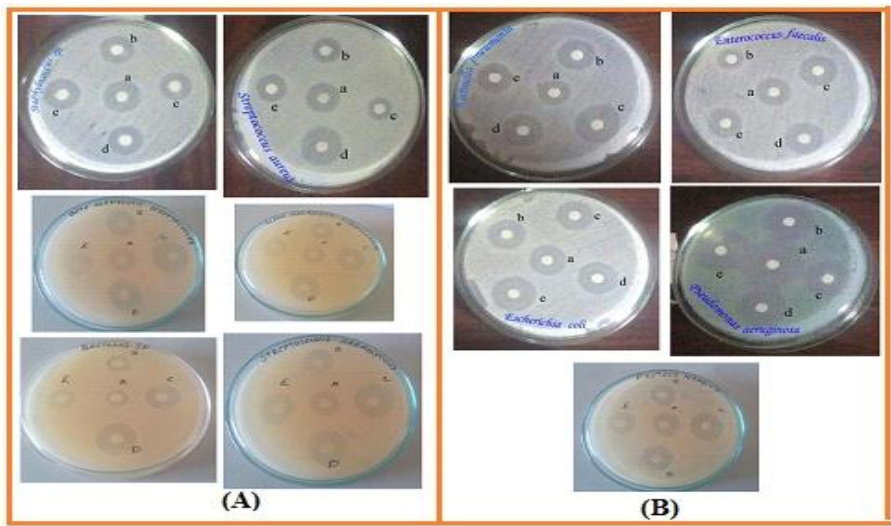

(a) Ampicillin ( Std.)

(b) Pure Silver Solution

(c) Pure Plant Extract (Control)

(d) Synthesized AgNPs

(e) Synthesized AgNPs + Std.

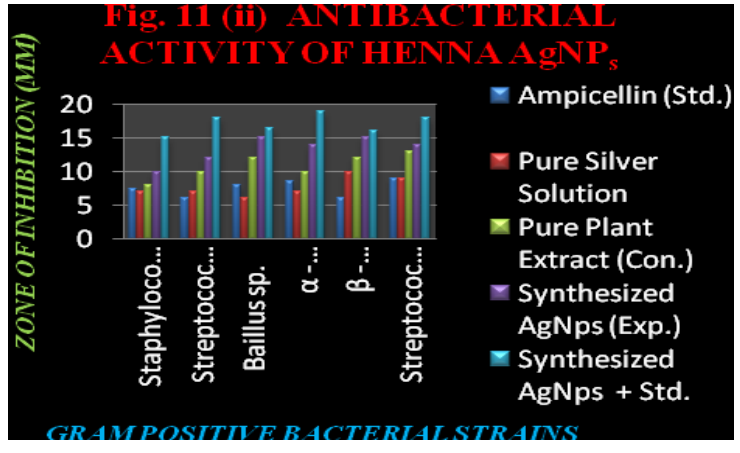

\section{Anti - bacterial Activty}

The antibacterial activity, the Ag- NPs showed activity against Five Gram Positive Bacterial Strains Viz. Stapylococcus sps, Streptococcus aureus, Alpha- haemolytic Streptococcus sps Beta- haemolytic Streptococcus sps., Bacillus sps., Streptococcus haemolyticus and Five Gram Negative Bacterial Strains like Enterococcus faecalis, Escherichia coli, Proteus mirablis, Pseudomonas aruginosa, Klebsiella pneumonia. In Gram Positive Bacterial Strains the highest antibacterial effect were observed in Alpha- haemolytic

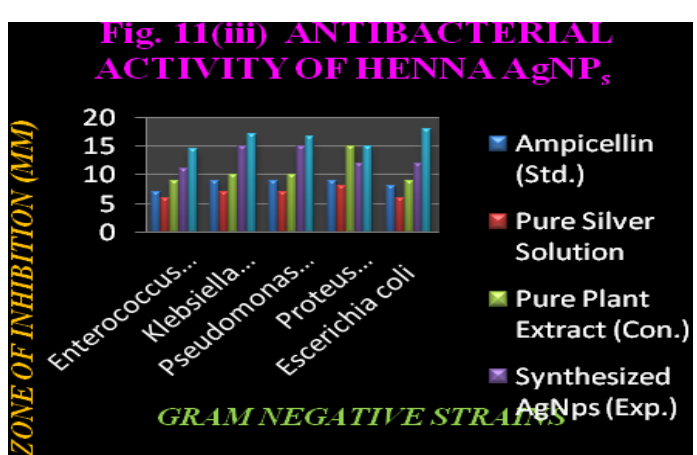

Streptococcus sps was found with zone of inhibition $(19 \mathrm{~mm})$ and lowest antibacterial effect in Ag-NPs on Stapylococcus sps. (15mm). The Ag-NPs also showed activity against Streptococcus aureus, Betahaemolytic Streptococcus sps., Bacillus sps., Streptococcus haemolyticus with zone of inhibition ranging from (16-18 mm). Results were summarized in figure 11 (i) \& (ii) and shown in Table ( $1 \& 2$ ). Comparison of the Ag-NPs combined with antibiotics (Ampicillin) data obtained in this study, the maximum activity was observed in Ag-NPs combined with antibiotics against all pathogens and minimum activity was 
observed in Standard, Pure Silver solution and Plant extract (control). Ag-NPs combined with antibiotics was also showed good zone of inhibition range between (15$19 \mathrm{~mm}$ ), were summarized in figure 12(iii) \& (iv). In the case of Gram Negative Bacterial Strains the maximum zone of inhibition or higher anti-bacterial activity was found in Escherichia coli (18mm) and lowest effect was recorded in Enterococcus faecalis $(14.5 \mathrm{~mm})$.

The mechanism which silver nanoparticles act to cause antimicrobial effect is not clearly known and is a debated topic, but there are various theories focusing on the action of silver nanoparticles on microbes to cause the microbicidal effect. The silver nanoparticles have the ability to anchor to the bacterial cell wall and subsequently penetrate and followed by the disruption of ATP production and DNA replication, thereby causing structural changes in the cell membrane and death of the cell. Evidently report of some authors mentioned that there is the formation of "pits" on the cell surface when accumulating these nanoparticles on the cell surface ${ }^{(20-24)}$ and causes damage to the microbes.

In conclusion, A simple \& environmental free green route was used to synthesize the $\mathrm{AgNP}_{\mathrm{s}}$ from silver nitrate using the aqueous extract of Lawsonia inermis (Henna) plant. The effect of Lawsonia inermis aqueous extract showed colloidal grey colour. From $\mathrm{UV}$ Vis spectrum synthesized $\mathrm{AgNP}_{\mathrm{s}}$ were shown characteristic peak at 461 in visible light regions. From XRD \& SEM studies revealed that the synthesized $\mathrm{AgNP}_{\mathrm{s}}$ shows spherical in shape with average particle size around $13-61 \mathrm{~nm}$ with EDX Potential of $3.68 \mathrm{keV}$ with percentage of silver at $65.91 \%$ and $28.27 \%$. The ZETA Potential shows the particles were stable at $-23.5 \mathrm{mV}$ and these particles present in $1 \mathrm{ml}$ is about 4.65 .The
Anti-bacterial activity of synthesized AgNPs showed much promising positive results.

\section{References}

1. Rai .M, Yadav .A. (2009). Silver nanoparticles as a new generation of antimicrobials; Biotechnol. Adv., 27(1), PP: 76-83.

2. Fendler,J.H.,(1992).Membrane Mimetic chemistry appsroach to advanced material; Springer-Verlag, Berlin.

3. Henlein, A., and Bunseng,(1995). Ber., Phys, Chem.,99, 903 - 913.

4. Weller, H., Angew. (1993). Chem., Int. Ed. Engl., 32, 41 - 53.

5. Colvin,V.L., Schlamp,M.C., and Alivisatos, A.P.(1994). Nature; 370, 354 $-357$.

6. Brus,L.E., (1984). Journal of Chem. Phys. Sciences; 80, 4403 - 4409.

7. Henglein,A., (1993). Jour. Of Phys. Chem sciences; 97, 5457 - 5464.

8. Alivisatas, A.P., (1996). Science, 271, $933-937$.

9. Butenko, A., Chubakov, P., Danilova, Y., (1990). Phys. Z., Atoms, D., mol. Clust. $17,283$.

10. Gutierrez, M., Henglein, A., (1993). Journal of Physical and Chemical Sciences; 97, 11368.

11. Pillai, Z., Kamat, P., (2004). Journal of Phys. Chem. B; 108, 945.

12. Shankar, S., Ahamed, A., Daricha, R., Sastry,M., (2003). Journal of Mater. Chem;13, 1822.

13. Sondi, I., and Salopex - Sondi, B., (2004). Silver Nanoparticles as antimicrobial agent: A case study on $E$. Coli as a model for Gram-Negative ; Jou. Colloid. Interface. Sci. 275 : 177 - 182.

14. Singh, A., and Singh, D.K., (2001). Indian journal of Exp. Bio. 39 : $263-$ 268.

15. Giri, L.R., Kholke, S.V., and Tayade, D.T., (2012). Oriental Journal of Chemistry; 28(1): 603 - 606. 
16. Shiharta, I.M., Hussain, A.G., and Mayah G.Y., (1978). Egypt Journal of Vetnary Science . 15: 31 .

17. Vaidyratnam, P.S., (1995). Indian Medicinal Plants. A Compendium of 500 Species, Vol.III, Botanical Survey of India, Ministry of Environment and Forests, India, 303 - 304.

18. Lavhate M.S., Mishra S.H. (2007), A review : Nutrional and therapeutic potential of Ailanthus excels ; Pharmacognosy Rev., 1(1): PP 105-113.

19. Siddqui B.S., Kardar M.N., Ali S.T. (2003), Two new and a known compound from Lawsonia inermis ; Helv. Chim. Acta, 86 (6), PP 2164-2169.

20. Abhishek, M., Akhilesh Kushwaha, Vandana Dalakoti, Garima Dalkoti and Deep Shinka Singh, (2014). Green Synthesis of Silver Nanoparticles using medicinal plant and its characterization . Der. Pharmacia. Sinica. \%(5): 118 - 122.

21. Debabrat, B., Nakul Sharma and Rituparna Bora., (2012). Green synthesis of Silver Nanoparticles using Bryophyllum pinnatum (Lam) and monitoring their antimicrobial activities; Arch. Appl. Sci. Res.4(5) : 2098 - 2104.

22. Jayakumar, D., Jhancy Mary, S., and Jayasanthi, R., (2010). Evaluation of antiOxidant potential and Anti-Bacterial activity of Calotropis gigantean and Vinca rosea using in-vitro model, Ind. J. Sci. Technol., 3(7): $720-723$.

23. Ranjithkumar, R., Selvam kuppasamy and Shanmugavadivu., (2003). Green synthesis of Silver Nanoparticles using Areca nut extract for enhanced anti - bacterial activity ; Jour. Green Sci. Technol; $1: 102-106$.

24. Shankar, S.S., Ahamad, A., and Sastry, M., (2003). Geranium leaf assisted biosynthesis of Silver Nanoparticles, Biotechnol. Prog; 19(6):1627 - 1631.

25. Shanmugavadivu, M., Selvam Kuppusamy and Ranjithkumar, R., (2014). Synthesis of Pomogranate Peel Extract mediated Silver Nanoparticles and its Anti - Bacterial activity; Am. Jour. Adv. Drug Del., 2 (2): 174 - 182.

26. Usha, C., and Gladys Angelin Rachel, D., (2014). Biogenic Synthesis of Silver Nanoparticles by Acacia nilotica and their Anti-Bacterial Activity. Int. Jour. Scientific res; 3(6): $27-29$.

27. Kathireswari, P., Gomathi, S., and Saminathan, K., (2014). Green Synthesis of Silver Nanoparticles using Vitex negundo and its Anti-Microbial Activity against Human Pathogens. International Journal of Current Microbiology and Applied Sciences; 3(8): $614-621$.

28. Wiley, B.J., Xiong, Y., Lizy., Yin, Y., Xia, Y., (2006). Right bipyramids of Silver : A new shape derived from Single twinned seeds : Nano Lett. 6:765 - 768.

29. Saminathan, K., (2015). Herbal Synthesis of Silver Nanoparticles using Eclipta alba and its Anti-Microbial Activity ; International Journal of Current Microbiology and Applied Sciences; 4(3): 1092 - 1097.

30. Agarry, O., Olaleye, M.T., Bello Michael, C.O., (2005). Comparative Antimicrobial activities of Aloe vera gel and leaf Afr. Jour. Biotechnolol 4: 1413 - 1414.

\section{How to cite this article:}

Satheesh Kumar, K., and Kathireswari, P. 2016. Biological synthesis of Silver nanoparticles (Ag-NPS) by Lawsonia inermis (Henna) plant aqueous extract and its antimicrobial activity against human pathogens. Int.J.Curr.Microbiol.App.Sci. 5(3): 926-937. doi: http://dx.doi.org/10.20546/ijcmas.2016.503.107 